\title{
Macroinvertebrates' Pollution Tolerance Index in Calabar River, Cross River State, Nigeria
}

\author{
Bate G.B. ${ }^{1, *}$ and Sam-Uket N.O. ${ }^{2}$ \\ ${ }^{1}$ Environmental Science Department, Federal University Dutse, Jigawa state, Nigeria \\ ${ }^{2}$ Animal and Environmental Biology Department, Cross River University of Technology, Calabar, Nigeria \\ *Corresponding Author: bategarba@yahoo.com
}

https://doi.org/10.36263/nijest.2019.02.0154

\begin{abstract}
A study was undertaken to determine the macroinvertebrates pollution tolerance index (PTI) in Calabar River, Cross River state, Nigeria. Five sampling stations were chosen along the river course: Ikot Okon Abasi, Tinapa, Unicem, Marina resort and Nsidung beach which were labeled stations 1, 2, 3, 4 and 5 respectively. Physico-chemical parameters; surface water temperature, $p H$, dissolved oxygen (DO), biochemical oxygen demand (BOD), total dissolved solids (TDS) and total suspended solids (TSS) were measured using their respective meters while macroinvertebrates were sampled using a Van Veen grab, stained with Rose Bengal solution and identified under microscope. Macroinvertebrates pollution tolerance index was obtained using online software designed by Northern Kentucky Univeristy and Leaf Pack Network Biotic and Water Quality Calculator. The results obtained for physicochemical parameters showed the highest temperature as 29.90C in station five while the lowest was 26.40C in station one. pH was highest (6.60) in station five and lowest (5.52) in station one. DO was highest $(4.4 \mathrm{mg} / \mathrm{L}$ ) in station four and lowest $(3.0 \mathrm{mg} / \mathrm{L})$ in station five while BOD was highest $(3.2 \mathrm{mg} / \mathrm{L})$ in station three and lowest $(0.3 \mathrm{mg} / \mathrm{L})$ in station one. An average total of 5366 macroinvertebrate individuals were encountered belonging to nine families and eleven species. Tubificidae had the lowest occurrence with 18 individuals which made up $0.3 \%$ of the total macroinvertebrates while Penaeidae had the highest occurrence with 2,455 individuals constituting $45.8 \%$ of the total count. Pollution tolerance index was highest (21) in station five and lowest (9) in station four with the water quality being generally poor. Hence, it is suggested that anthropogenic activities should be regulated and continuous monitoring of the river course should be carried out.
\end{abstract}

Keywords: Macro-invertebrates, Pollution tolerance index, Calabar River, Physicochemical parameters, Sensitivity factor, Abundance code.

\subsection{Introduction}

Macroinvertebrates are organisms without backbones, which are visible to the eye without the aid of a hand lens or microscope. They consist of the immature stages of many flies, beetles (adult and immature), mayflies, caddis flies, stoneflies, dragonflies, aquatic worms, snails, and numerous other organisms (Idowu and Ugwumba, 2005). They serve as useful bioindicators of aquatic health status due to their high functional and taxonomic diversity, ubiquity, tolerance of wide environmental gradients, rapid, and often predictable response to environmental changes of natural and anthropogenic origin. They are generally sessile or sedentary, have relatively long life spans and are thus indicative of changing water qualities by reflecting cumulative effects of the present and past conditions of short and long term environmental stressors (Meyer et al., 2007; Olomukoro and Dirisu, 2014). The use of macroinvertebrates in monitoring the overall health status of an environment is more efficient than using chemical and microbiological data, which give short-term fluctuations while macroinvertebrates give a better representation of the environmental quality (George et. al., 2009). 
Certain taxa or groups of organisms are known to be more or less tolerant of polluted conditions of an environment and the presence or absence of these organisms can be used to evaluate the level of pollution or human disturbance of that environment and is assigned a value used in calculating the pollution tolerance index (PTI). The use of pollution tolerance index (PTI) as a method of measuring the overall health status of aquatic bodies through the use of macro-invertebrates remains the most reliable and effective method (Andem et. al., 2015). Macroinvertebrates which are used in aquatic pollution studies include: Mayflies (Ephemeroptera), caddisflies (Trichoptera), stoneflies (Plecoptera), beetles (Coleoptera), crayfish and amphipods (Crustaceans), aquatic snails (Mollusca), biting midges (Chironomids) and leeches (Hirudinea) among others (Oku et al., 2014).

Several studies reported signs of pollution from untreated industrial effluents, municipal wastewater, run-off from agricultural chemical fertilizers and pesticides, as well as spillage of petroleum products in Calabar River (Okoroafor et al., 2013; Reuben et al., 2016). This study is undertaken to evaluate the pollution tolerance index of macroinvertebrates in Calabar River, Nigeria.

\subsection{Materials and Methods}

\subsection{Study area}

The Calabar River in Cross River State, Nigeria is located between latitude 040 55' $55^{\prime \prime}$ to 05002 ' 50 'N and longitude $008016^{\prime} 35^{\prime \prime}$ to $008018^{\prime} 13.8^{\prime \prime} \mathrm{E}$. It flows from the north through the city of Calabar, joining the larger Cross River to the south (Figure 1). Five sampling stations with an average distance of $4.5 \mathrm{~km}$ from one another were chosen along the river course: Ikot Okon Abasi, Tinapa, Unicem, Marina resort and Nsidung beach which were labeled stations 1, 2, 3, 4 and 5 respectively. This choice was from upstream downwards at points where human activities such as fishing, tourism, bathing and discharge of wastes take place.

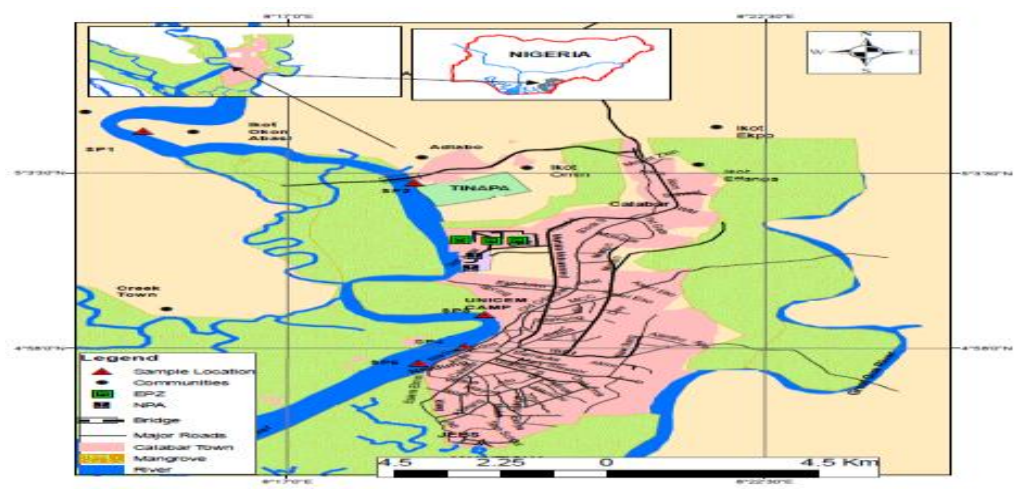

Figure 1: Map of study area showing Calabar River and sampling stations

\subsection{Physico-chemical parameters measurement}

The physico-chemical parameters measured are; surface water temperature, $\mathrm{pH}$, dissolved oxygen (DO), biochemical oxygen demand (BOD), total dissolved solids (TDS) and total suspended solids (TSS) were measured using their respective meters during the period of this study.

\subsection{Macroinvertebrates collection}

A Van Veen grab was used for each sampling, 3 or 4 hauls were made by sending the grab down into the bottom of the river at random locations. The sediment collected were poured into a labeled white plastic can of about $20 \mathrm{~cm} 3$ in volume and taken to the laboratory for analysis. In the laboratory, the sediment was passed through three sieves of $2 \mathrm{~mm}, 1 \mathrm{~mm}$ and $0.5 \mathrm{~mm}$ mesh sizes to collect the benthos. The benthos were poured into a white enamel tray, stained with Rose Bengal solution to 
highlight the hidden features and sorted using forceps. They were sorted out into different taxa and preserved in $4 \%$ formalin. They were then identified under a stereoscope microscope using identification guides of Pennak (1978) and EPA (1998) and counted. In case of stony substrate, stones were lifted to remove the animals that are hidden in between and a sweep net of mesh size $0.5-1 \mathrm{~mm}$ was used to collect flying macro-invertebrates.

\subsection{Pollution Tolerance Index}

Pollution Tolerance Index (PTI) of macroinvertebrates from the five sampling stations in Calabar River was obtained using online software designed by Northern Kentucky Univeristy and Leaf Pack Network Biotic and Water Quality Calculator. Macroinvertebrate families were assigned into three groups, namely pollution intolerant, moderately tolerant, and tolerant. Each category was then scored with a sensitivity factor; a factor of 3 was given to the pollution sensitive (intolerant) group, a factor of 2 to the moderately tolerant group, and a factor of 1 to the pollution tolerant group. The total number of each macroinvertebrate family was assigned an abundance code viz: $\mathrm{R}$ (rare) $=1-9$ organisms, $C($ common $)=10-99$ organisms and $\mathrm{D}$ (dominant $)=\geq 100$ organisms. Pollution tolerance index is the sum of abundance codes multiplied by the indicated sensitivity factors. Values obtained were thereafter compared with established standard values in accordance with George et al., (2017). A PTI value of 22 and above is rated excellent, 16-21 is good, 11-15 is fair while 10 or less is poor.

\subsection{Results and Discussion}

\subsection{Physico-chemical parameters}

The highest temperature was $29.90 \mathrm{C}$ in station five, the lowest was $26.40 \mathrm{C}$ in station one. $\mathrm{pH}$ was also highest in station five and lowest in station one with 6.60 and 5.52 respectively while dissolved oxygen (DO) ranged from 3.0 to $4.4 \mathrm{mg} / \mathrm{l}$. Biochemical oxygen demand (BOD) was lowest in station one and highest in station three. Mean measures of physico-chemical parameters during the study are shown in table one.

Table 1: Mean Physico-chemical parameters of Calabar River during the study

\begin{tabular}{lcccccc}
\hline Parameters & $\mathrm{S}_{1}$ & $\mathrm{~S}_{2}$ & $\mathrm{~S}_{3}$ & $\mathrm{~S}_{4}$ & $\mathrm{~S}_{5}$ & NESREA Limits \\
\hline Surface Water temperature $\left({ }^{0} \mathrm{C}\right)$ & 26.40 & 27.4 & 27.8 & 28.7 & 29.9 & $20-40$ \\
$\mathrm{pH}$ & 5.52 & 5.67 & 5.97 & 6.22 & 6.60 & $6.0-9.0$ \\
Dissolved Oxygen (DO) mg/L & 4.3 & 4.3 & 4.2 & 4.4 & 3.0 & 5.0 \\
Biochemical Oxygen Demand (BOD5) $\mathrm{mg} / \mathrm{L}$ & 0.3 & 2.3 & 3.2 & 1.7 & 1.7 & 10 \\
Total suspended solids (mg/L) & 13.0 & 16.0 & 14.0 & 15.0 & 23.5 & $<10$ \\
Total Dissolved Solids (mg/L) & 24.12 & 26.58 & 44.73 & 50.02 & 95.76 & 500 \\
\hline
\end{tabular}

Physicochemical parameters give some clue about the overall pollution status of a water body as they are influenced by effluents from industries or domestic and agricultural wastes (Kidu et al., 2015). pH was generally low in all the sampling stations and meet the NESREA standard only in stations four and five. Dirisu et al. (2016) found out that decomposition of organic matter within a body of water, releases carbon dioxide, which combines with water to form carbonic acid. Also, the presence of some metals such as aluminum, copper and zinc as well as releasing acidifying pollutants into the atmosphere and water bodies bring about low pH. Dissolved oxygen (DO) was below the NESREA standard which indicates moderate pollution of the river while Biochemical oxygen demand (BOD) was within the standard during the study. 


\subsection{Macroinvertebrates abundance, composition and distribution}

An average total of 5366 individual macroinvertebrates made up of nine families and eleven species were encountered in all the sampling stations from Calabar River during the study. The macroinvertebrate taxon with the lowest occurrence was Tubificidae which constitute $0.3 \%$ of the total population while Penaeidae was the highest with about 45.8\%. Table two shows the macroinvertebrates composition and distribution during the study.

Table 2: Composition and relative abundance of macroinvertebrates of Calabar River during the study

\begin{tabular}{|c|c|c|c|c|c|c|c|}
\hline Family & Species & $\mathrm{S}_{1}(\%)$ & $\mathrm{S}_{2}(\%)$ & $\mathrm{S}_{3}(\%)$ & $\mathrm{S}_{4}(\%)$ & $\mathrm{S}_{5}(\%)$ & Total $(\%)$ \\
\hline Palaenomidae & Macrobrachium vellenhovenii & $87(10.0)$ & $102(9.2)$ & $87(6.9)$ & $68(13.1)$ & $140(8.6)$ & $484(9.1)$ \\
\hline Penaeidae & Peneaus notalis & $295(33.9)$ & $472(42.5)$ & $701(56.3)$ & $146(28.1)$ & $841(51.8)$ & $2,455((45.8)$ \\
\hline Ocypodidae & Uca tangeri & $73(8.4)$ & $92(8.3)$ & $102(8.2)$ & $66(12.7)$ & $113(6.9)$ & $446(8.3)$ \\
\hline Portunidae & Callinates amnicola & $58(6.7)$ & $64(5.8)$ & $59(4.7)$ & $43(8.3)$ & $90(5.5)$ & $314(5.9)$ \\
\hline Limnephilidae & Pycnopsyche species & $12(1.4)$ & $10(0.9)$ & $5(0.4)$ & $13(2.5)$ & $4(0.3)$ & $44(0.8)$ \\
\hline Libellulidae & Crocothemis erythra & $11(1.2)$ & $8(0.7)$ & $7(0.6)$ & $10(1.9)$ & $3(0.2)$ & $39(0.7)$ \\
\hline Neritidae & Neritina afra & $116(13.3)$ & $134(12.1)$ & $71(5.7)$ & $42(8.1)$ & $72(4.4)$ & $435(8.1)$ \\
\hline \multirow[t]{3}{*}{ Thiaridae } & Pachymelania fusca & $89(10.2)$ & $95(8.6)$ & $105(8.4)$ & $61(11.7)$ & $127(7.8)$ & $477(8.9)$ \\
\hline & Melanoides tubercula & $63(7.2)$ & $70(6.3)$ & $58(4.7)$ & $31(5.9)$ & $126(7.8)$ & $348(6.5)$ \\
\hline & Pachymalenia byronensis & $57(6.5)$ & $59(5.3)$ & $49(3.9)$ & $35(6.7)$ & $106(6.5)$ & $306(5.7)$ \\
\hline Tubificidae & Tubifex tubifex & $8(0.9)$ & $4(0.4)$ & $1(0.1)$ & $4(0.7)$ & $1(0.1)$ & $18(0.3)$ \\
\hline \multicolumn{2}{|c|}{ Total No of Individuals } & 869 & 1110 & 1245 & 519 & 1623 & 5366 \\
\hline
\end{tabular}

Macroinvertebrates composition, abundance and distribution as presented in table two are highly influenced by the pollution status of a water body. About $73 \%$ of the total macroinvertebrates encountered in this study were pollution tolerant. James et al. (2018) assessed Zambezi River water quality using macroinvertebrates population diversity and the measured $\mathrm{pH}$, temperature, dissolved oxygen and conductivities suggested varying degrees of contamination where sixty-two macroinvertebrates made up of nine different species were recorded at two sampling points with $54.84 \%$ of them being highly pollution tolerant. Macroinvertebrates tend to move away from an unfavourable environment though they are slow or sessile in nature. Akindele and Liadi (2014) stated that these organisms reside in an aquatic system long enough to reflect the chronic effects of pollutants, and yet short enough to respond to relatively acute changes in water quality.

\subsection{Pollution Tolerance Index}

Station four had the lowest pollution tolerance index of 9 while the highest was 21 in station five. Figure 2 shows the pollution tolerance indices of the sampling stations during the study.

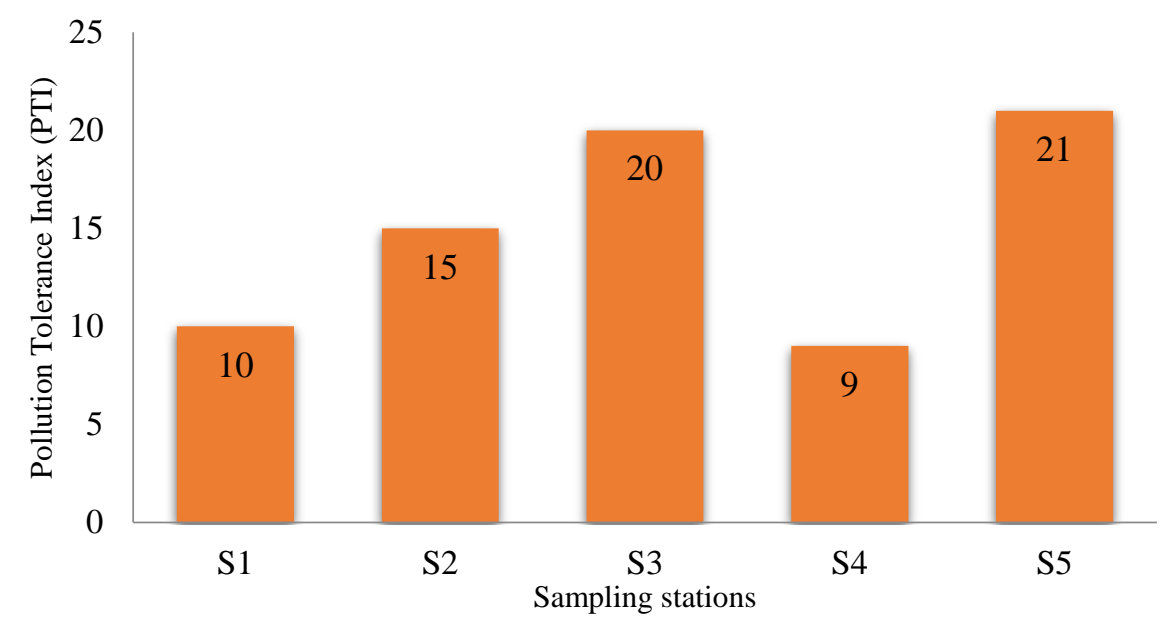

Figure 2: A Chart showing macroinvertebrate Pollution Tolerance Indices (PTIs) of Calabar River at various sampling stations 
Stations one and four had pollution tolerances indices (PTIs) of less than or equal to $10(\leq 10)$ which is an indication of poor water quality. Station two had a PTI of 15 which is fair while stations three and five had good water qualities. This further confirms that the river has been contaminated especially at those sampling stations with low PTIs. Several cases of pollution such as heavy metals, petroleum hydrocarbons, pesticides and solid wastes were reported in Calabar River and its surrounding (Agbaji and Ejemot-Nwadiaro, 2019; Eddy et al., 2004; Nsikak and Joseph, 2009). Andem et al., (2015) found a similar result in their study on Ediba River, Cross River state, Nigeria where two out of the three sampling stations had PTIs $<10$ which indicates very poor water quality.

\subsection{Conclusion}

This study, from physicochemical parameters to the macroinvertebrates pollution tolerance index found out that Calabar River is moderately polluted. It is therefore recommended that anthropogenic activities should be regulated and continuous monitoring of the river course should be carried out.

\section{References}

Agbaji D. A. and Ejemot-NwadiaroR. (2019). Solid Waste Management in Calabar Metropolis: Case Study of Calabar Urban Development Authority (2008 - 2017). Greener Journal of Medical Sciences, 9(1): 17-31.

Akindele E. O. and Liadi A. A. (2014). Diversity and Response of Benthic Macroinvertebrates to Natural and Induced Environmental Stresses in Aiba Stream, Iwo, Southern Nigeria. West African Journal of Applied Ecology, 22(1):101-111.

AndemA. B., Esenowo I. K. and Bassey D. O. (2015). Application of Biotic Indices and Pollution Tolerance Index in Assessing Macro-Invertebrate Assemblage of Ediba River, Cross River State, Nigeria. Journal of Environmental and Analytical Toxicology, 37: 1-9.

Dipankar G., Jayanta K. B. and Juan C. S. (2017). Efficiency of Pollution Tolerance Index (PTI) of Macroinvertebrates in Detecting Aquatic Pollution in Oxbow Lake, India. Universitas Scientiarum, 22 (3): $237-261$.

Dirisu C. G., Mafiana M. O., Dirisu G. B. and Amodu R. (2016). Level of pH in Drinking Water of an Oil and Gas Producing Community and Perceived Biological and Health Implications. European Journal of Basic and Applied Sciences, 3(3): 53-60.

Environmental Protection Agency (EPA) (1998). Lake and Reservoir Bioassessment and Biocriteria. Technical Guidance Document, 841: 98-107.

Eddy N. O., Udo C. L. and Ukpong I. J. (2004). Heavy Metals in the Sediment of Cross River Estuary at Oron, South Eastern Nigeria. African Journal of Environmental Pollution and Health, 3(1): 6-10.

George A. D., Abowei J. F. and Alfred-Ockiya J.F. (2009). The Distribution, Abundance and Seasonality of Benthic Macro-invertebrates in Okpoka Creek Sediment, Niger Delta, Nigeria. Resource Journal of Applied Science and Engineering Technology, 2: 11-18.

George U., Inyang-Etor A. and Friday E. (2017). Biotic Index Assessment of Human Perturbations in Qua Iboe River Estuary Using Macro-Benthic Invertebrate as Indicator Organisms. Journal of American Science, 13(9): 98-107.

Idowu, E. O. \& Ugwumba, A. A. (2005). Physical, Chemical and Benthic Faunal Characteristics of a Southern Nigeria Reservoir. The Zoologist, 3:15-25.

James A., Evans K. S. and Dietlinde N. N. (2018). Assessment of Zambezi River Water Quality using Macroinvertebrates Population Diversity. Journal of Fisheries and Aquatic Science, 13(1): 12-20. 
Kidu M., Abraha G., Amanual H. and Yirgaalem W. (2015). Assessment of Physico-chemical Parameters of Tsaeda Agam River in Makelle City, Tigram, Ethiopia. Bulletin of Chemical Society of Ethiopia, 29(3): 377-385.

Leaf Pack Network® Biotic and Water Quality Calculator, https://leafpacknetwork.org/biotic-index/

Meyer J. L., Strayer D. L., Wallace J. B., Eggert S. L., Helfman G. S. and Leonard N. E. (2007). The contribution of headwater streams to biodiversity in river networks, Journal of the American Water Resources Association, 43: 86-103.

National Environmental Standards and Regulations Enforcement Agency (NESREA) (2011). National Environmental (Surface and Ground Water Quality): 693-727.

Nsikak U. B. and Joseph P. E. (2009). Petroleum HydrocarbonContamination of Sediments and Accumulation in Tympanotonusfuscatusvar. radula from the Qua Iboe Mangrove Ecosystem, Nigeria. Current Science, 96(2): 238-244.

Okoroafor K. A., Effanga E. O., Andem A. B., George U. U. and Amos D. I. (2013). Spatial Variation in Physical and Chemical Parameters and Macro-Invertebrates in the Intertidal Regions of Calabar River, Nigeria. Greener Journal of Geology and Earth Sciences, 1(2): 62-72.

Oku E. E., Andem A. B., Arong B. G. and Odjadjare E. (2014) Effect of Water Quality on the Distribution of Aquatic Entomofauna of Great Kwa River, Southern Nigeria. American Journal of Engineering Research 3: 265-270.

Olomukoro J. O. and Dirisu A. R. (2014). Macroinvertebrate Community and Pollution Tolerance Index in Edion and Omodo Rivers in Derived Savannah Wetlands in Southern Nigeria. Jordan Journal of Biological Sciences, 7(1): 19-24.

Pennak, E. (1978). A field guide to Africa fresh water snails. West African species, WHO snail identification centre. Danish Bilharziasis Laboratory, 34: 5-15.

Reuben N. O., Raphael B. J. and Faith N. C. (2016). Combined Effects of Municipal and Industrial Wastes on the Quality of the New Northern Calabar River, Nigeria. International Journal of Water Resources and Environmental Engineering, 8(8): 103-112.

WHO (2004). Guidelines for Drinking-water Quality.Geneva: World Health Organization.

\section{Cite this article as:}

Bate, G.B. and Sam-Uket, N.O., 2019. Macroinvertebrates' Pollution Tolerance Index in Calabar River, Cross River State, Nigeria. Nigerian Journal of Environmental Sciences and Technology, 3(2), pp. 292-297. https://doi.org/10.36263/nijest.2019.02.0154 